\title{
First observation of true vivipary in Grindelia squarrosa (Asteraceae)
}

\author{
Artur Pliszko ${ }^{1}$ (D) Artur Górecki ${ }^{1}$ (D) \\ Received: 17 December 2020 / Accepted: 9 February 2021 / Published online: 19 February 2021 \\ (C) The Author(s) 2021
}

\begin{abstract}
In flowering plants, true vivipary is defined as the precocious seed germination and the growth of the embryo to a considerable size before dispersal. True vivipary occurs mostly in mangroves and is very rare in Asteraceae. In this study, we present the first observation of true vivipary in Grindelia squarrosa, a North American member of Asteraceae, from a new locality in Poland. We examined 50 fruiting capitula which were collected in October 2020 in Brzegi, southern Poland. True vivipary occurred in $90 \%$ of capitula; however, the number of germinated seeds was low (3.42 on average) and very variable $(\mathrm{CV}=106 \%)$. Seed germination was found only in fruits developed from disc flowers. We presumed that precocious seed germination in G. squarrosa was induced by prolonged rainfall. The importance of true vivipary in naturalization and invasion of G. squarrosa as well as the involvement of viviparous seedlings in autochory should be further explored.
\end{abstract}

Keywords Autochory $\cdot$ Dimorphic fruits $\cdot$ Naturalization $\cdot$ Precocious seed germination

\section{Introduction}

In flowering plants, vivipary is understood as the precocious and continuous growth of the offspring when it is still attached to the maternal plant (Elmqvist and Cox 1996). Depending on the origin of the offspring (sexual or asexual reproduction) two types of vivipary, true vivipary and pseudovivipary, are distinguished. True vivipary describes the precocious seed germination (sexually produced offspring) and the growth of the embryo to a considerable size before dispersal (detachment from the maternal plant). Pseudovivipary, in contrast, describes the formation and growth of apomictic or asexual propagules such as bulbils or plantlets in the place of sexual reproductive structures of the maternal plant (Elmqvist and Cox 1996; Chauhan et al. 2018). Vivipary is a rare phenomenon in plants and it has been documented in less than $0.1 \%$ of angiosperms (195 species, 143 genera, and more than 80 families) including both wild and cultivated species (Elmqvist and

Artur Pliszko

artur.pliszko@uj.edu.pl

1 Department of Taxonomy, Phytogeography and Palaeobotany, Institute of Botany, Faculty of Biology, Jagiellonian University in Kraków, Gronostajowa 3, 30-387 Kraków, Poland
Cox 1996; Cota-Sánchez and Abreu 2007; Anand and Mathur 2012; Chauhan et al. 2018; Karmakar et al. 2019). Generally, true vivipary occurs mostly in tropical species (especially in mangroves), whereas pseudovivipary is found mostly in arctic, alpine, and desert species (Elmqvist and Cox 1996; CotaSánchez and Abreu 2007). True vivipary and pseudovivipary are unique and adaptive strategies. Elmqvist and Cox (1996) suggested that while both viviparous and non-viviparous strategies can persist in coarse-grained environments, only nonviviparous strategies may persist in fine-grained environments, where there is subtle and rich variation between patches in both time and space. Nevertheless, in some cases, vivipary is caused by pathogens and other stress factors (Elmqvist and Cox 1996; Karmakar et al. 2019 and references therein). In Asteraceae, vivipary occurs sporadically being confirmed in Abrotanella linearis Berggr., Ageratina adenophora (Spreng.) R.M.King \& H.Rob., Bidens pilosa L., Dendrosenecio johnstonii (H.H.Johnst.) B.Nord., Eclipta prostrata (L.) L., Saussurea lappa (Decne.) Sch.Bip., Tagetes erecta L., and Taraxacum officinale F.H.Wigg. (Karmakar et al. 2019 and references therein).

Grindelia squarrosa (Pursh) Dunal, a biennial or a shortlived perennial plant of Asteraceae, is native to North America (Steyermark 1934; Bartoli and Tortosa 2012). Its native range comprises the central prairie and plains region from southern Minnesota and South Dakota south into south-eastern 
Wyoming, Iowa, Nebraska, Kansas, and Texas in the USA (Steyermark 1934). It occurs in arid habitats such as sagebrush steppe, desert grasslands, prairies, and mountain shrub chaparral. Moreover, it is often found as a weed on roadsides, open fields, and in poorly managed pastures and rangelands (Steyermark 1934; Tilley and Pickett 2016 and references therein). It was introduced to other parts of North America, Europe, Asia, and Australia (Randall 2017 and references therein; Shevera et al. 2019). Grindelia squarrosa was introduced to Europe in 1804 as a cultivated plant in the Royal Garden of Madrid (Steyermark 1934; Sîrbu and Oprea 2008). The first records of $G$. squarrosa outside cultivation were reported from Belgium (1920), Lithuania (1946), and Ukraine (1949). Currently, it is naturalized in six European countries (i.e., Bulgaria, Romania, Moldova, Ukraine, Poland, and Russia) (Shevera et al. 2019; Zając and Zając 2019). It was also naturalized in Georgia (Jinjolia and Shakarishvili 2014). So far, invasion of $G$. squarrosa has been observed in Romania, Moldova, and Ukraine (Shevera et al. 2019). Outside of its native range, G. squarrosa is found mostly in ruderal places, along roadside verges and railway embankments, as well as along the banks of rivers (Sîrbu and Oprea 2008; Vladimirov and Petrova 2012; Jinjolia and Shakarishvili 2014; Tilley and Pickett 2016; Tokaryuk et al. 2018). This plant is well adapted to disturbed areas with low precipitation, high elevation, low nutrient, and large variations in temperature (Tilley and Pickett 2016; Tokaryuk et al. 2018; Shevera et al. 2019). Moreover, G. squarrosa is commonly cultivated as an ornamental and medicinal plant (Shevera et al. 2019).

Grindelia squarrosa forms two types of flowers (female ray flowers and bisexual disc flowers) which are arranged in a capitulum. Fruits (achenes) developed from ray and disc flowers differ in their morphology and seed germination. Fruits developed from ray flowers (referred to hereinafter as ray achenes or ray fruits) are short and angular, with thick pericarp, whereas fruits developed from disc flowers (referred to hereinafter as disc achenes or disc fruits) are long, flattened, and with thin pericarp (McDonough 1975). Seed germination in disc fruits occurs more rapidly and seeds attain higher final germination percentages over a broader range of temperatures than seeds of ray fruits. Some seeds of both types have a light requirement for germination, but the proportion is much lower in seeds of disc fruits. Moreover, low-temperature stratification increases the range of conditions suitable for germination of both types of achenes but has a greater effect on disc achenes (McDonough 1975). This differentiation of the germination process allows the emergence of seedlings during different seasons and consequently affects the time required for completion of the growth cycle (McDonough 1975). Vivipary in G. squarrosa has not been observed so far. In this study, we present the first report of true vivipary in $G$. squarrosa from a new locality in Poland.

\section{Materials and methods}

\section{Study area and population characteristics}

The study was conducted in Brzegi near Kraków, Lesser Poland Province, southern Poland (GPS coordinates: $50^{\circ} 02.085^{\prime} \mathrm{N}, 20^{\circ} 04.969^{\prime} \mathrm{E}$, elevation: $194 \mathrm{~m}$ a.s.1.), in October 2020. The study area lies in a temperate climate zone where the mean annual air temperature is about $8.5^{\circ} \mathrm{C}$ and the mean annual precipitation is about $700 \mathrm{~mm}$ (Lorenc 2005, data for years 1971-2000). This is the second known locality of Grindelia squarrosa in Poland (Zając and Zając 2019). According to Zajacc (1978), it is situated in the unit EF60 (a square of $10 \mathrm{~km}$ side) of the ATPOL cartogram grid (Fig. 1). Grindelia squarrosa was found growing on roadside verges between fish ponds of „Brzegi” Ecological Site and wasteland of „Brzegi” Aggregate Mine, on 20 September 2020. The population consisted of 74 clusters of generative ramets (shoots with capitula) which were distributed along the roadside verges by the distance of about $50 \mathrm{~m}$. The clusters comprised from 1 to 22 generative ramets. Grindelia squarrosa was accompanied by ruderal plant species such as native Artemisia vulgaris L., Cirsium arvense (L.) Scop., Equisetum arvense L., Plantago major L., Tanacetum vulgare L., Tussilago farfara L. and alien Erigeron annuus (L.) Pers., Panicum capillare L., Setaria pumila (Poir.) Roem. \& Schult., and Solidago gigantea Aiton. Most likely it was introduced by humans with rubble and soil or with garden waste. Seed germination within the capitula of $G$. squarrosa was accidentally noticed on 2 October 2020, during the floristic survey in Brzegi.

\section{Plant materials and data analysis}

On 14 October 2020, ten clusters of G. squarrosa were randomly selected for investigation. In each cluster, five capitula with mature fruits were randomly sampled to estimate the percentage of vivipary. In the laboratory, fresh fruits were separated from capitula to check the number of welldeveloped ray and disc fruits, as well as the number of germinated seeds. Basic descriptive statistics including mean, standard error, standard deviation, and coefficient of variation were calculated for assessed parameters. The ray and disc fruits were identified based on their morphology following the illustration presented by McDonough (1975). The seed was determined as germinated when the pericarp of the fruit was broken showing cotyledons, hypocotyl, or root of at least $1 \mathrm{~mm}$ length. Herbarium specimens of G. squarrosa are deposited in the Herbarium of the Institute of Botany of the Jagiellonian University in Kraków (KRA 0557627 , 0557628, 0557629). Photographic documentation is presented in Fig. 2. 
Fig. 1 Distribution of Grindelia squarrosa in Poland using the ATPOL cartogram grid (black circle indicates previously known locality; black triangle indicates new locality described in this study)

Fig. 2 Grindelia squarrosa in Brzegi, southern Poland: a specimen with flowering and fruiting capitula; $\mathbf{b}, \mathbf{c}, \mathbf{d}-$ selected fruiting capitula showing true vivipary (Photographed by A. Pliszko and A. Górecki)
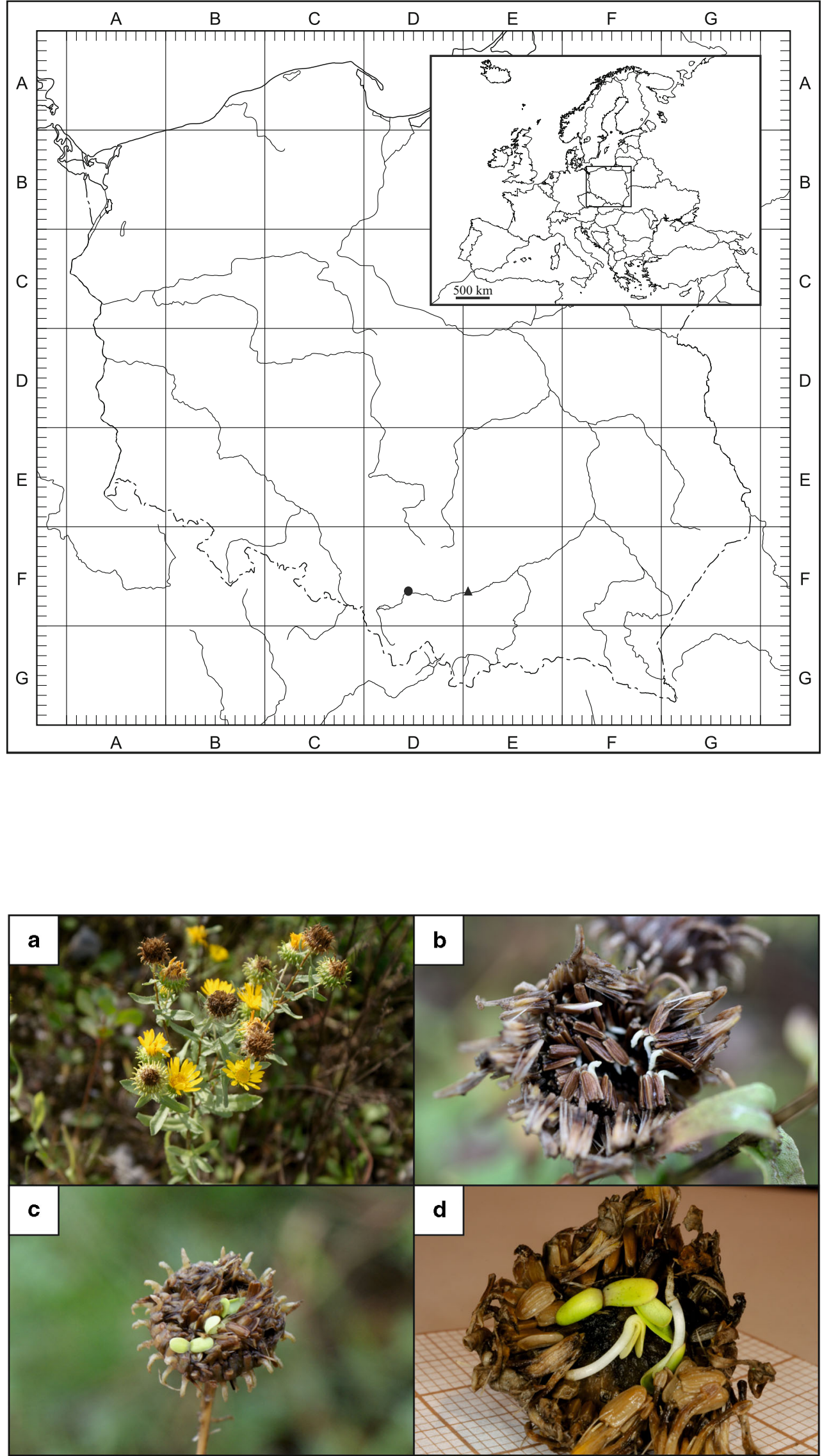


\section{Results and discussion}

True vivipary (precocious seed germination) occurred in all selected clusters of ramets including $90 \%$ of capitula examined. Germinated seeds were found only within disc fruits reaching $4.63 \%$ of disc fruits and $2.23 \%$ of the total number of fruits. The number of germinated seeds in a capitulum varied greatly $(\mathrm{CV}=106 \%)$, reaching an average of 3.42 . Moreover, the number of fruits per capitulum was similar in both fruit morphs (ray and disc achenes), and the observed variation among capitula was rather low (Table 1).

We presumed that precocious seed germination in disc fruits of $G$. squarrosa was induced by prolonged rainfall. During the floristic survey in Brzegi, we noticed that the capitula of $G$. squarrosa with germinated seeds were wet inside. Between 24 September and 14 October 2020, there were only four days with no rainfall in Brzegi. In this period, the precipitation, air temperature, and air humidity ranged $0.0-12.7 \mathrm{~mm}, 6-26{ }^{\circ} \mathrm{C}$, and $42-$ $97 \%$, respectively (after weather data on https://pogoda.wp.pl/ archiwum-pogody/brzegi). It was repeatedly suggested that high humidity as a result of continuous rainfall promotes true vivipary in non-mangrove plants. Anand and Mathur (2012) evidenced that during continuous rainfall, the capitula of Tagetes erecta get wet and the seeds begin to germinate inside the capitula forming the seedlings. Similarly, in the case of Hedychium elatum R.Br. (Bhadra et al. 2013), Ageratina adenophora (Karmakar and Hazra 2016), Saussurea lappa (Chauhan et al. 2018), and Bidens pilosa (Karmakar et al. 2019), true vivipary was induced by high monsoon rainfall. Also, in some cereals, seeds germinate on the maternal plants if they get enough moisture. Moreover, it was suggested that vivipary depends on excessive moisture within fruits like lemons, oranges, tomatoes, and melons (Anand and Mathur 2012 and references therein). Nevertheless, other factors like air temperature, sunlight, and soil properties could be also involved in true vivipary (Anand and Mathur 2012).

Our results confirmed that seeds of disc fruits in $G$. squarrosa germinate easier than seeds of ray fruits as suggested by McDonough (1975). This can be explained by a lack of seed dormancy and the structure of the pericarp

Table 1 Summary statistics for selected features of Grindelia squarrosa $(\mathrm{N}=50)$

\begin{tabular}{lllll}
$\begin{array}{l}\text { Summary } \\
\text { statistics }\end{array}$ & $\begin{array}{l}\text { Number of } \\
\text { germinated } \\
\text { seeds }\end{array}$ & $\begin{array}{l}\text { Number of } \\
\text { ray achenes in } \\
\text { capitulum }\end{array}$ & $\begin{array}{l}\text { Number of } \\
\text { disc achenes } \\
\text { in capitulum }\end{array}$ & $\begin{array}{l}\text { Total number } \\
\text { of achenes in } \\
\text { capitulum }\end{array}$ \\
\hline Min-Max & $0-22$ & $18-152$ & $7-138$ & $32-282$ \\
Mean & 3.42 & 79.34 & 73.78 & 153.12 \\
SE & 0.51 & 4.88 & 5.06 & 9.23 \\
STD & 3.62 & 34.54 & 35.79 & 65.28 \\
CV [\%] & 106 & 44 & 49 & 43 \\
\hline
\end{tabular}

enabling the disc fruits fast imbibition in contrast to dormant seeds of ray fruits which form thick pericarp (McDonough 1975). There are many other plant species with differences in seed dormancy between fruit morphs (Flint and Palmblad 1978 and references therein). In such species, seed germination is distributed in time and space shaping their growth cycles. McDonough (1975) evidenced that G. squarrosa plants emerging in the fall overwinter and acting as winter annuals complete their life cycle during the next growing season and these plants are derived largely from disc achenes. In Ukraine, G. squarrosa is a biennial or rarely an annual plant (Tokaryuk et al. 2018). During our field surveys in Brzegi, we also found seedlings of G. squarrosa under maternal clusters of ramets. We expect that young plants appearing in fall can complete their life cycle in the next growing season. Moreover, we expect that the flowering clusters of $G$. squarrosa will not survive to the next season since they did not produce leaf rosettes at the base of the shoots.

According to Tokaryuk et al. (2018) and Shevera et al. (2019), G. squarrosa is a polychorous species that can be dispersed by wind, animals, water, and humans (agestochory). However, the structure of the pappus bristles (Jinjolia and Shakarishvili 2014) does not allow the plant to spread by wind over long distances. The location of ray and disc fruits in the capitulum affects their dispersal. Disc fruits, which are situated in the center, separate more easily from the receptacle than do ray fruits, which are situated in the peripheral part of the capitulum, where the phyllaries are usually folded making their dispersal difficult and delayed (McDonough 1975). Moreover, phyllaries as leaves and stems of G. squarrosa are covered with resinous glands that exude a sticky resin (Rose and Strandtmann 1986) to which the fruits may occasionally stick after separation from the receptacle. When discussing the true vivipary in G. squarrosa, it would be worthwhile to draw attention to the possibility that seedlings emerging inside the capitulum can push other fruits (with germinated or non-germinated seeds) outside the capitulum allowing autochorous dispersal. Such a mechanism of autochory has not been considered in G. squarrosa so far. It is also worth mentioning that true vivipary serves to avoid intraspecific competition increasing the survival of seedlings before they mature (Karmakar et al. 2019).

Production of numerous seeds, various modes of seed dispersal, and no seed dormancy are considered as factors promoting naturalization and invasion of many alien plants (Richardson and Pyšek 2011, Gioria and Pyšek 2017 and references therein). According to Tokaryuk et al. (2018 and references therein), one individual of G. squarrosa can produce up to 24000 or sometimes more than 261000 fruits per year. In our study, the number of well-developed fruits per capitulum in G. squarrosa was also relatively high (Table 1). In Poland, G. squarrosa is treated as a naturalized species (Zając and Zając 2019); however, it has the potential to become invasive in the future. Interestingly, Karmakar et al. 
(2019) suggested that true vivipary may facilitate the invasion of $B$. pilos $a$ in the region of Darjeeling in the Himalayas if young seedlings are dispersed on mountain slopes during the monsoon. The number of germinated seeds in capitula of $G$. squarrosa in Brzegi was low and very variable suggesting that true vivipary in this species is occasional and weather dependent. On the other hand, the plant has the potential to sustain true vivipary in areas where the climate is more humid. Nevertheless, further studies are needed to explain the importance of true vivipary in the naturalization and invasion of $G$. squarrosa as well as to explain the involvement of viviparous seedlings in autochory.

Acknowledgements We thank the Reviewers for their positive comments and valuable suggestions, which helped us to improve the manuscript. We also thank Doctor Sauren Das (Agricultural and Ecological Research Unit, Indian Statistical Institute in Kolkata) and Doctor Robin Lesher (Northwest Science) for allowing access to some references.

Author contributions AP - research conceptualization, sample design and methodology, investigation and data collection, data analysis and interpretation, manuscript writing and editing; AG - investigation and data collection, data analysis and interpretation, manuscript writing and editing.

\section{Declarations}

Conflict of interest The authors declare no conflict of interest.

Open Access This article is licensed under a Creative Commons Attribution 4.0 International License, which permits use, sharing, adaptation, distribution and reproduction in any medium or format, as long as you give appropriate credit to the original author(s) and the source, provide a link to the Creative Commons licence, and indicate if changes were made. The images or other third party material in this article are included in the article's Creative Commons licence, unless indicated otherwise in a credit line to the material. If material is not included in the article's Creative Commons licence and your intended use is not permitted by statutory regulation or exceeds the permitted use, you will need to obtain permission directly from the copyright holder. To view a copy of this licence, visit http://creativecommons.org/licenses/by/4.0/.

\section{References}

Anand N, Mathur A (2012) Occurrence of vivipary behavior in Tagetes erecta L. Eur J Exp Biol 2:2317-2319

Bartoli A, Tortosa RD (2012) Revision of the North American Species of Grindelia (Asteraceae). Ann Missouri Bot Gard 98:447-513. https://doi.org/10.3417/2008125

Bhadra S, Ghosh M, Mukherjee A, Bandyopadhyay M (2013) Vivipary in Hedychium elatum (Zingiberaceae). Phytotaxa 130:55-59. https://doi.org/10.11646/phytotaxa.130.1.7

Chauhan RS, Bahuguna YM, Nautiyal MC, Cota-Sánchez JH (2018) First account of vivipary in Saussurea lappa (Decne.) Sch. Bip. (Asteraceae). Braz J Bot 41:507-514. https://doi.org/10.1007/ s40415-018-0450-3
Cota-Sánchez JH, Abreu DD (2007) Vivipary and offspring survival in the epiphytic cactus Epiphyllum phyllanthus (Cactaceae). J Exp Bot 58:3865-3873. https://doi.org/10.1093/jxb/erm232

Elmqvist T, Cox PA (1996) The evolution of vivipary in flowering plants. Oikos 77:3-9

Flint SD, Palmblad IG (1978) Germination dimorphism and developmental flexibility in the ruderal weed Heterotheca grandiflora. Oecologia 36:33-43

Gioria M, Pyšek P (2017) Early bird catches the worm: germination as a critical step in plant invasion. Biol Invasions 19:1055-1080. https:// doi.org/10.1007/s10530-016-1349-1

Jinjolia L, Shakarishvili N (2014) Grindelia squarrosa (Pursh) Dunal - a new alien genus and species for flora of Georgia. Bull Georgian Natl Acad Sci 8:64-68

Karmakar NC, Hazra A (2016) First evidences for induced pseudoviviparous germination in Ageratina adenophora (Crofton weed), a common alien weed of Darjeeling Himalaya, India. Plant Sci Today 3:249-257. https://doi.org/10.14719/pst.2016.3.3.234

Karmakar NC, Hazra A, Das S (2019) Bidens pilosa L.: Exclusive report of vivipary in a non-mangrove taxa from the eastern Himalayas. Plant Species Biol 34:122-126. https://doi.org/10.1111/1442-1984. 12237

Lorenc H (ed) (2005) Atlas klimatu Polski. Instytut Meteorologii i Gospodarki Wodnej, Warszawa

McDonough WT (1975) Germination polymorphism in Grindelia squarrosa (Pursh) Dunal. Northwest Sci 49:190-200

Randall RP (2017) A Global Compendium of Weeds, 3rd edn. RP Randall, Western Australia, Perth

Richardson DM, Pyšek P (2011) Naturalization of introduced plants: ecological drivers of biogeographical patterns. New Phytol 196: 383-396. https://doi.org/10.1111/j.1469-8137.2012.04292.x

Rose FL, Strandtmann RW (1986) Wildflowers of the Llano Estacado. Taylor Publishing Company, Dallas

Shevera M, Kucher O, Zavialova L, Bzdega K, Nowak T, Zarychta A, Tokarska-Guzik B (2019) Grindelia squarrosa: economically useful or an invasive plant in Europe? In: Pyšek P, Pergl J, Moodley D (eds) 15th Ecology and Management of Alien Plant invasions (EMAPi) book of abstracts: Integrating research, management and policy. Institute of Botany, Czech Academy of Sciences, Průhonice, p 183

Sîrbu C, Oprea A (2008) Two alien species in the spreading proces in Romania: Reynoutria $\times$ bohemica Chrtek \& Chrtková and Grindelia squarrosa (Pursh) Dunal. Cercet Agron Mold 41:41-50

Steyermark JA (1934) Studies in Grindelia. II. A Monograph of the North American Species of the Genus Grindelia. Ann Missouri Bot Gard 21:433-608

Tilley D, Pickett T (2016) Plant Guide for curlycup gumweed (Grindelia squarrosa). USDA-Natural Resources Conservation Service. Aberdeen Plant Materials Center, Aberdeen, ID. 83210

Tokaryuk AI, Chorney II, Budzhak VV, Protopopova VV, Shevera MV, Kucher OO (2018) Grindelia squarrosa (Pursh) Dunal (Asteraceae) in Chernivtsi Region (Ukraine). Biol Systems 10:67-72. https://doi. org/10.31861/biosystems2018.01.067

Vladimirov V, Petrova AS (2012) Grindelia squarrosa: a new alien species for the Bulgarian flora. Phytol Balc 18(3):315-318

Zając A (1978) Atlas of distribution of vascular plants in Poland. Taxon 27:481-484. https://doi.org/10.2307/1219899

Zając A, Zając M (eds) (2019) Distribution atlas of vascular plants in Poland: appendix. Institute of Botany, Jagiellonian University, Kraków

Publisher's note Springer Nature remains neutral with regard to jurisdictional claims in published maps and institutional affiliations. 